\title{
Effects of Spraying Ozone Water on Resistance Physiology and Yield of Vegetables
}

\author{
Rongrong Tian ${ }^{1, \mathrm{a}}$, Tianhong Zhao ${ }^{1, \mathrm{~b}^{*}}$ and Hongyan $\mathrm{Wu}^{1, \mathrm{c}}$ Lin $\mathrm{Mu}^{1, \mathrm{~d}}$ \\ ${ }^{1}$ Agronomy College, Shenyang Agricultural University, Shenyang, China \\ a2240460750@qq.com, bzth1999@163.com, '1321412149@qq.com d11486001@qq.com \\ ${ }^{*}$ Corresponding author
}

Keywords: Ozone water; Antioxidant; SOD; POD

\begin{abstract}
Objective: the use of ozone to prevent and control the disease and insect pests of vegetables has made some achievements in birth, but its mechanism is not clear. By spraying ozone water in this paper, from the point of plant physiology, the effects of ozone water spraying on the physiological and yield of vegetable resistance were discussed. Methods: cucumber and tomato were used as experimental material. The test set two treatments: CK: spraying water, T: spraying ozone water. The water was sprayed by the ozone water solution of $50 \mathrm{~kg}$ with ozone aeration of 45 min. Results: the results showed that spraying ozone water could improve SOD and POD activities of cucumber and tomato, reduce electrical conductivity and MDA content, and increase yield by increasing single fruit weight. Conclusion: Spraying ozone water can increase the antioxidant enzyme activity of vegetables, but the negative effects on vegetables need to be further studied.
\end{abstract}

\section{Introduction}

Ozone $\left(\mathrm{O}_{3}\right)$ is composed of 3 oxygen atoms. It is a strong oxidizing agent. The half-life of the normal temperature is $20 \mathrm{~min}$, and the natural vanishing rate is fast. It is easy to decompose (about a few minutes to a few minutes from ozone to oxygen) and easy to dissolve in water. In 1839 , the German chemist Schonbein found that ozone, after more than 200 years [1], from the beginning of the disinfection by ozone water, now widely used in water treatment, air purification, food storage[2], fresh fruits and vegetables, food processing[3], medical and health, aquaculture, livestock and agricultural facilities and other industries and fields[4].

The mechanism of action is to destroy the structure of microbial membrane through its strong oxidation, then destroy the lipoproteins and lipopolysaccharides in the membrane, and change the permeability of membranes, so that cells can dissolve and die [5]. Ozone water has the characteristics of quick response and no drug resistance. Ozone will be decomposed into oxygen and water around 40min after ozone water application, and it has the advantages of safety, innocuity and no irritation. Therefore, ozone is called "ideal green strong oxidant"[6].

According to the biological characteristics of ozone, there are some studies on the prevention and control of vegetable diseases and pests in the facility agriculture. Zhou Shengjun et al[7] studies showed that using $50 \mathrm{~kg}$ water to treat $20 \mathrm{~m}^{2}$ soil by ozone aeration 45 and $90 \mathrm{~min}$, the effect of tomato bacterial wilt prevention was significant, and the control effect against Tomato Bacterial Wilt increased by $26.5 \%-35.7 \%, 25.7 \%-35 \%$, respectively, which significantly increased tomato yield $24.4 \%-54.1 \%$. Li Yi et al [8] found that the best concentration of ozone released in greenhouse is $0.8-1 \mathrm{mg} / \mathrm{m}^{3}$, which can effectively control greenhouse vegetable diseases and insect pests, and will not cause damage to the growth and development of vegetables. Ding Ming et al [9] studies showed that spraying ozone water was beneficial to the growth of cucumber, and increased the photosynthetic rate of cucumber seedlings and increased the activity of CAT, SOD and POD.

It is undoubtedly an effective solution to the problem of pesticide residue. However, Liu Dilin et al [10] believed that ozone is a strong oxidant, ozone can be used for sterilization and disinfection, but the lowest concentration for sterilization was much higher than the concentration of harmful plants, and ozone can harm the plant, resulting in crop production, so using ozone to prevent disease was not advisable for growing greenhouse crops. Therefore, the effect of ozone water on vegetable 
diseases and insect pests needs further verification. The purpose of this experiment is to study the effect of ozone water on cucumber and tomato physiology, and to explore the feasibility of ozone application in cucumber and tomato production.

\section{Materials and methods}

Experimental design. Cucumber and tomato were used as experimental material. This study was conducted at the Agronomy College at Shenyang Agricultural University. The test set two treatments: CK: spraying water, T: spraying ozone water. The water was sprayed by the ozone water solution of $50 \mathrm{~kg}$ with ozone aeration of $45 \mathrm{~min}$. The seedlings were transplanted in May 3, 2017. After the growth was stable, the plants began to be treated in May 18th. They were sprayed every 7 days in the whole growth period. The samples were sampled 20 days later and sampled every 20 days, namely, 20, 40, and 60 days after treatment. The samples of cucumber and tomato were selected for the determination of the indexes. Each treatment was repeated 3 times, and 6 plots were set up, each area was $4 \mathrm{~m} \times 1 \mathrm{~m}$.

Measurement method of index. Superoxide dismutase (SOD) was determined by nitrogen tetrazolium four (NBT) method; peroxidase (POD) activity was measured by guaiacol assay ; The relative conductivity was measured by DDS-11A type conductivity meter; the content of MDA was determined by thiobarbituric acid method[11];Yield determination: in each treatment, ten plants were selected for yield determination, and weighing method was used to determine fruit weight of single plant, number of single fruit and quality of single fruit respectively.

Statistics. All statistical analyses were performed using Microsoft Excel 2010 and SPSS 22.0. One-way ANOVA analysis was applied to the same cultivar under different water treatments. Duncan multiple difference method was used to compare the differences.

\section{Conclusions}

Effects of spraying ozone water on SOD and POD activities of cucumber and tomato leaves. As shown in Table 1, when 20d was treated, the SOD enzyme activity of cucumber leaves was as follows: $\mathrm{CK}>\mathrm{T}$ and reached a significant level $(\mathrm{p}<0.05)$. When 40d and 60d were treated, the SOD activity of spraying ozone water treatment was higher than that of control $11.2 \%$ and $17.7 \%$, and all reached a significant level $(\mathrm{p}<0.05)$. Compared with $\mathrm{CK}$, in each period the POD activity of cucumber leaves under the treatment of spraying ozone water was higher than that of the control, and all reached a significant $(\mathrm{p}<0.05)$ level. The above results showed that spraying ozone water could improve the antioxidant enzyme activity of cucumber leaves and improve the resistance of cucumber.

Table 1 Changes of SOD and POD activity of cucumber and tomato leaves under ozone water spraying

\begin{tabular}{cccccc}
\hline \multirow{2}{*}{ Indexes } & \multirow{2}{*}{ Day } & \multicolumn{2}{c}{ Cucumber } & \multicolumn{2}{c}{ Tomato } \\
\cline { 3 - 6 } & & \multicolumn{1}{c}{$\mathrm{CK}$} & \multicolumn{1}{c}{$\mathrm{T}$} & \multicolumn{1}{c}{$\mathrm{CK}$} & $\mathrm{T}$ \\
\hline $\mathrm{SOD}$ & 20 & $125.90 \pm(7.3) \mathrm{a}$ & $71.24 \pm(5.6) \mathrm{b}$ & $216.41 \pm(3.4) \mathrm{a}$ & $211.56 \pm(8.5) \mathrm{a}$ \\
{$\left[\mathrm{U} \cdot \mathrm{g}^{-1} \mathrm{FW}\right]$} & 40 & $287.36 \pm(8.3) \mathrm{b}$ & $319.46 \pm(1.8) \mathrm{a}$ & $182.74 \pm(6.9) \mathrm{a}$ & $188.64 \pm(2.2) \mathrm{a}$ \\
& 60 & $271.42 \pm(5.4) \mathrm{b}$ & $319.48 \pm(9.6) \mathrm{a}$ & $132.82 \pm(1.3) \mathrm{b}$ & $141.87 \pm(3.6) \mathrm{a}$ \\
$\mathrm{POD}$ & 20 & $2.64 \pm(0.05) \mathrm{b}$ & $3.33 \pm(0.14) \mathrm{a}$ & $0.51 \pm(0.01) \mathrm{b}$ & $0.55 \pm(0.01) \mathrm{a}$ \\
{$\left[\mathrm{Umg}^{-1} \cdot \mathrm{min}^{-1} \mathrm{FW}\right]$} & 40 & $3.15 \pm(0.12) \mathrm{b}$ & $4.24 \pm(0.11) \mathrm{a}$ & $0.54 \pm(0.01) \mathrm{b}$ & $0.60 \pm(0.01) \mathrm{a}$ \\
& 60 & $2.26 \pm(0.08) \mathrm{b}$ & $4.53 \pm(0.13) \mathrm{a}$ & $1.04 \pm(0.06) \mathrm{b}$ & $1.76 \pm(0.06) \mathrm{a}$ \\
\hline
\end{tabular}

Note: $n=3$, the letters in the Table indicate that the difference between different treatments reached 0.05 significant levels, the same as below.

As shown in Table 1, in the treatment of 20d, SOD enzyme activity in tomato leaves was CK>T, but the difference was not significant $(\mathrm{p}>0.05)$; the treatment of 40d, the activity of SOD showed: $\mathrm{T}>$ CK, but did not reach significant level ( $p>0.05)$; the treatment of $60 \mathrm{~d}$, the activity of SOD as follows: $\mathrm{T}>\mathrm{CK}$, and reached significant level $(\mathrm{p}<0.05)$. Compared with $\mathrm{CK}$, the POD activity of 
cucumber leaves under ozone water treatment was higher than that of $\mathrm{CK}$ at all times, and all of them reached a significant $(\mathrm{p}<0.05)$ level. In the treatment of $60 \mathrm{~d}$, POD activity of ozone water treatment was $69.8 \%$ higher than that of control. In general, the effect of spraying ozone water on the SOD activity of tomato leaves was not significant, but it could significantly increase the activity of POD.

Effects of spraying ozone water relative conductivity of cucumber and tomato leaves. As shown in Table 2, under the spraying ozone water treatment, in each period the relative conductivity of cucumber leaves were lower than the control; Table 2 showed that in addition to the treatment of $40 \mathrm{~d}$, the relative conductivity of the other two periods of tomato leaves were lower than that of the control, indicating that the spraying ozone water can effectively relieve the damage of cell function and decrease the exosmotic of the intracellular electrolyte.

Table 2 Effects of spraying ozone water Relative conductivity and MDA of cucumber and tomato leaves.

\begin{tabular}{crrrrr}
\hline \multirow{2}{*}{ Indexes } & \multirow{2}{*}{ Day } & \multicolumn{2}{c}{ Cucumber } & \multicolumn{2}{c}{ Tomato } \\
\cline { 3 - 6 } & & \multicolumn{1}{c}{$\mathrm{CK}$} & \multicolumn{1}{c}{$\mathrm{T}$} & \multicolumn{1}{c}{$\mathrm{CK}$} & $\mathrm{T}$ \\
\hline Relative & 20 & $26.96 \pm(3.89) \mathrm{a}$ & $25.96 \pm(2.19) \mathrm{a}$ & $27.81 \pm(1.10) \mathrm{a}$ & $26.77 \pm(0.50) \mathrm{a}$ \\
conductivity & 40 & $26.81 \pm(3.05) \mathrm{a}$ & $26.13 \pm(2.83) \mathrm{a}$ & $28.33 \pm(1.73) \mathrm{b}$ & $31.24 \pm(0.23) \mathrm{a}$ \\
{$[\%]$} & 60 & $33.45 \pm(0.46) \mathrm{a}$ & $31.54 \pm(1.30) \mathrm{a}$ & $21.45 \pm(0.83) \mathrm{a}$ & $19.13 \pm(1.18) \mathrm{b}$ \\
$\mathrm{MDA}$ & 20 & $5.04 \pm(0.26) \mathrm{a}$ & $2.94 \pm(0.19) \mathrm{b}$ & $1.86 \pm(0.19) \mathrm{a}$ & $2.90 \pm(0.09) \mathrm{b}$ \\
{$\left[\mathrm{mmol} \cdot \mathrm{g}^{-1} \mathrm{FW}\right]$} & 40 & $2.07 \pm(0.07) \mathrm{b}$ & $0.98 \pm(0.23) \mathrm{a}$ & $3.47 \pm(0.30) \mathrm{b}$ & $2.57 \pm(0.23) \mathrm{a}$ \\
& 60 & $1.44 \pm(0.30) \mathrm{b}$ & $1.31 \pm(0.14) \mathrm{a}$ & $4.93 \pm(0.24) \mathrm{b}$ & $4.44 \pm(0.19) \mathrm{a}$ \\
\hline
\end{tabular}

Effects of spraying ozone water MDA of cucumber and tomato leaves. As shown in Table 2, the content of MDA in cucumber leaves was lower than that of $\mathrm{CK}$ at all times and reached a significant level in the treatment of $20 \mathrm{~d}$ and $40 \mathrm{~d}(\mathrm{p}<0.05)$. Table 2 showed the effect of ozone water spraying on the MDA content of tomato leaves. As shown in the Fig. 8, in addition to 20d treatment, the MDA content in two other periods under ozone water spraying was lower than that in the control, which was similar to that in cucumber. The possible reason is that the spraying of ozone water reduced the damage of pathogen to leaves, relieved the damage of the cells and decreased the degree of lipid peroxidation in the cell membrane.

Effects of spraying ozone water on yield of cucumber and tomato. The yield of each treatment is shown in Table 3. From the table, we can see that under the ozone water spraying treatment, the fruit weight per plant, fruit number per plant and single fruit weight of cucumber increased by $9.76 \%, 2.41 \%$ and $7.18 \%$ compared with CK, respectively. The effect of each treatment on tomato yield was similar to that of cucumber. The fruit weight per plant and single fruit weight under ozone water spraying treatment were higher than that of control. But the fruit number per plant did not increase. Especially the fruit number per plant under ozone water treatment was lower than that of the control. The results showed that spraying ozone water could increase the yield of cucumber and tomato, and the spraying of ozone water could improve the weight of single fruit.

Table 3 Effect of ozone water spraying on yield of cucumber and tomato

\begin{tabular}{ccccc}
\hline vegetable & treatment & $\begin{array}{c}\text { fruit weight per plant } \\
{[\mathrm{kg} / \text { plant] }}\end{array}$ & $\begin{array}{c}\text { fruit number per plant } \\
\text { [number/plant] }\end{array}$ & $\begin{array}{c}\text { single fruit weight } \\
{[\mathrm{g}]}\end{array}$ \\
\hline \multirow{2}{*}{ cucumber } & $\mathrm{CK}$ & 1.56 & 8.3 & 186.67 \\
& $\mathrm{~T}$ & 1.71 & 8.5 & 200.06 \\
\multirow{2}{*}{ tomato } & $\mathrm{CK}$ & 1.21 & 10.6 & 113.81 \\
& $\mathrm{~T}$ & 1.24 & 9.6 & 129.46 \\
\hline
\end{tabular}




\section{Discussions}

Effects of spraying ozone water on antioxidant enzyme activity of cucumber and tomato leaves. Plant antioxidant enzyme system is one of the important defense systems for plants to cope with stress. It can effectively protect plants to reduce the damage to plants by environmental stress.

SOD is a scavenger of superoxide anion radicals in organism, which can effectively prevent their damage to organisms and is an important antioxidant enzyme in plants. POD is also a protective enzyme in plant enzymatic defense system, which can effectively catalyze the decomposition of hydrogen peroxide into water, thus effectively preventing the accumulation of hydrogen peroxide in plants and eliminating its potential damage to plant cell membrane structure.

The results showed that spraying ozone water could significantly increase the antioxidant enzyme activity of cucumber and tomato leaves, which was in agreement with the results of Ding Ming et al [9]. Under the action of ozone water, the antioxidant enzyme activity of cucumber and tomato was increased, and the resistance was increased. However, ozone water had different effects on antioxidant enzymes of two species. Spraying ozone water could significantly improve SOD and POD activities of cucumber leaves, but for tomato, the effect of ozone water on POD activity was more significant.

Effects of spraying ozone water on the relative conductivity and MDA of cucumber and tomato leaves. The relative conductivity is one of indexes to determine whether the plants are harmed by adversity. Due to the destruction of cell membrane damage or cell structure destruction, the cell permeability increased, various water soluble substances within the cell including the electrolyte will have different degrees of extravasation, the more serious injury, extravasation of more weight, the increase of conductivity is more serious. The results showed that spraying ozone water can reduce the relative conductivity of tomato and cucumber leaves, and slow down the extent of cell damage. The possible reason is that the sterilization effect of ozone water weakens the damage of pests and diseases to vegetables, and further reduces the conductivity of leaves. But on the 40 day, the relative conductivity of tomato leaves treated with ozone water treatment is significantly higher than that of the control. It may be that the oxidation of ozone water has certain damage on tomato leaves.

MDA is the final decomposed product of membrane lipid peroxidation, and it is the embodiment of the degree of membrane peroxidation of plant cells. Its content can reflect the degree of plant suffered by adversity. The high content of MDA indicates that the membrane of plant cells has a high degree of peroxidation, and the damage of the cell membrane is serious.

We can see from Table 2, spraying ozone water can significantly reduce the MDA content of cucumber leaves; in the early stage of processing ozone water brought harm effect on tomato leaves, and increased the content of MDA in tomato leaves, but with the prolonging of treatment time, limited the damage effect of ozone water, increased the protective effect, so the content of MDA in tomato leaves decreased, indicating that the degree of membrane lipid peroxidation decreased.

Effects of spraying ozone water of yield of cucumber and tomato. Studies have shown that the use of ozone to control pests and diseases in facilities is not only effective in reducing the incidence of diseases and insect pests, but also in increasing production. In the case of ozone water, the yield of cucumber and tomato increased, and the weight of single fruit increased significantly.

\section{Conclusion}

Ozone water spraying could improve the activity of SOD and POD in cucumber and tomato leaves and increase the resistance of plant leaves. The effect of ozone water on disease and insect, reduced the damage degree of leaves, and then reduced the content of MDA in the leaves, and the relative conductivity was also reduced. At the same time, under the spraying ozone water treatment cucumber and tomato have a certain increase in yield, and the main reason for increasing production in this experiment was to increase the weight of single fruit. 
The results showed that the effect of spraying ozone water on vegetables was different because of the variety and time of action. This experiment only used ozone water with a concentration. The ozone application in other vegetable diseases and insect pests and the choice of ozone concentration should be further studied.

\section{Acknowledgements}

This study was supported by the National Natural Science Foundation of China (31570404).

\section{References}

[1] Z. Q. Xia, J. Yang, C.W. Ding. Introduction of ozone disinfection, Chinese Journal of Chemical Education. 27(2006) : 7-9.

[2] X.C. He, R.J. Zhang, D.Q. Wang, et al. The influence of $\mathrm{O}_{3}$ fumigation on stored grain quality, Grain storage,31(2002):38- 41.

[3] Y.R. Hou, L. Niu, B.G. Wang, et al, Study on Sterilizing Technology of Ozone Water in Fresh-cut Apple, Food industry. 38(2017):121-125.

[4] Y.M. Li, Z. Yang, M. Z. Li, et al. The present situation and Prospect of the application of ozone in low carbon agriculture. Shaanxi Journal of Agricultural Sciences. 01(2013):113-115.

[5] X.Q. Wang, J.J. Cao, J.Q. ZHENG, et al, Research progress on controlling plant disease by ozone [J] . China Plant Protection. 21(2011):17-20.

[6] Y.S. Dai, W.K. Zhang, H.M. Wang, et al. Analysis of sterilizing effect of ozone and ozone water.Chinese Journal of Biologicals .17(2004):320-321.

[7] S.J. Zhou, S.Y. Wang, H.R. WAang, et al, Effects of ozone water on the control efficiency of bacterial wilt of tomato, Pseu-domonas solanacerum, Acta Agriculture Zhejiangensis.19(2007):216- 219.

[8] Y. Li, Y.M. Li, S.L. Zhang, et al, Application Effect of $\mathrm{O}_{3}$ on Control Disease \& Pest for Greenhouse Vegetables. Agricultural Engineering. 2(2012):31-34.

[9] M. Ding, Z.R. Zou , D.F. Huang, Research and Application of Ozone on Ccuumber Prdocution in Geernhouse, Jounral of Hua zhong Agrieultul Uranivers. 35(2004):119-124.

[10]D.L. Liu, J. Cai. Questions on the ozone application in greenhouse vegetable production, Transactions of the CSAE.21(2005): 221-224.

[11] Q. Zou. Experimental guidance in Plant Physiology, China Agriculture Press, Beijing, 2000. 